\title{
GLOBAL CHANGES AND NEW TRENDS WITHIN THE TERRITORIAL STRUCTURE OF THE OIL, GAS AND COAL INDUSTRIES
}

\author{
Milan Vošta*
}

\section{Introduction}

In the historical context, power engineering has played a crucial role in the creation of the territorial structure of economy and namely of industrial production. The power industry has significantly affected the localization of energy-intensive industries, which were attracted due to the underdeveloped transport as well as high cost of transport. Traditional industrial areas with high energy consumption thus became the main cores of the territorial structure of industrial production but also the centres of the economies of individual states and they were created against a background of energy resource extraction. The current trend is more characterized by the relation of secondary energy production to the main economic energy-intensive areas. Thanks to the substantially intensified transport of primary and secondary energy resources to places of consumption, it has at the same time prolonged the distances among the places of extraction, production and final use of the energy resource.

\section{Localization changes in the oil industry}

Localization changes in power engineering are significantly influenced by scientific and technological progress. Owing to new technologies, geological surveying is undertaken in increasingly remote territories, including seas. Thus, we can speak of a constantly growing energy dependence of a number of developed countries, including the EU Member States. Modern systems of transportation via pipelines enable the transportation of both oil and gas over long distances. The development of power engineering is a basic indicator of the economic level of both regions and individual states.

The world production of oil has been constantly rising. By the end of the 1970s the extraction of oil increased in response to growing consumption, namely in regions with

\footnotetext{
University of Economics, Prague, Faculty of International Relations, World Economy Department (vosta@vse.cz).

This paper was elaborated within the grant project of the Czech Science Foundation No. GA 402/07/0440

"Energy demandingness: a determinant of fossil fuels flow and implications for the EU and the Czech Republic".
} 
the most convenient natural and economic conditions. For this reason, some significant changes in the localization of the world extraction emerged. The most important change on the map of the world oil extraction was the advancement of extraction in the Eastern hemisphere - in the Near and Middle East, where the extraction was stimulated by lower costs as well as by a relative closeness to Western Europe. Growing prices also provided economic justification for the deposits in the North Sea and other areas where the extraction had not been profitable before. In 2004, the global oil production reached some 3,888 million tons compared to the year 1960, when it had been four times lower.

In the second half of the 20th century there occurred significant changes in the territorial structure of the oil industry both in the extraction itself as well as the location of refineries as a result of the global economic development and a growing demand for oil. Since the 1950s North America was losing its leading position in the extraction from half of the world extraction its share dropped to a mere fifth in the 1990s. The development in Asia fully corresponded to the sizes of its deposits and the Asian continent therefore entered the second half of the 1990s with a $40 \%$ share, putting it in the first place in oil extraction worldwide. At the same time, a drop in oil production in Eastern Europe as well as in North and Latin America was recorded.

\section{Figure 1}

\section{Dynamism of oil extraction during 1950 - 2004 (million tons)}

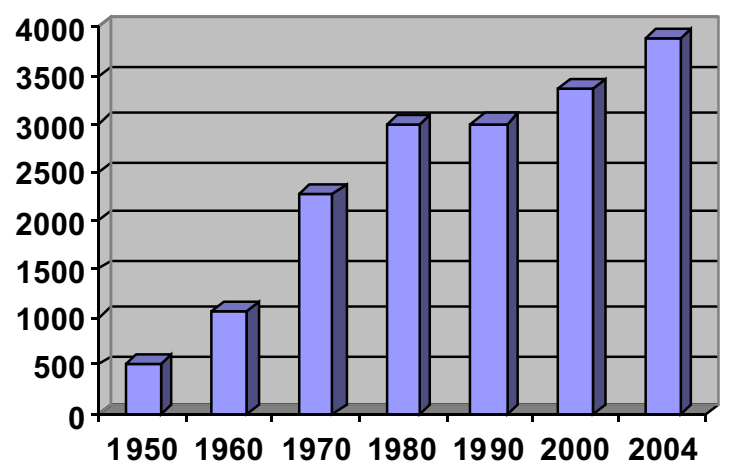

Source: Adapted by the author from Rodionova, I. A, Gunakova, T. M.: Ekonomičeskaja geografija. Moscow : Moskovskij licej, 2004, p. 122; Key World Energy Statistics 2005. Paris: International Energy Agency, 2005, p. 11; www.iea.org.

Besides changes at the regional level, the oil industry recorded significant territorial changes connected with the oil production in the individual states. Russia reduced its oil extraction and it tumbled from the leading position to the third place during the second half of the 1990s. The USA and Saudi Arabia became the leading extracting countries. The discoveries, survey and extraction of deposits in the North Sea enabled Norway and the UK to appear among the top ten oil producers worldwide. The 
late 1990s also saw a boost in the extraction in Nigeria, which became the first African country to attack a position among the ten biggest oil producers worldwide.

The analyzed trends in the localization of oil extraction in the last ten years significantly reduced the territorial concentration of the industry. Simultaneously, it is necessary to stress the formation of and changes in the territorial structure of the oil industry which are highly influenced by international trade in oil. While in 1950 the first ten countries extracted $94 \%$ of the world oil production, in 1980 the share of the ten most important oil extractors had dropped to $84 \%$. In 2004 the ten biggest oil producers shared $62.2 \%$ of the world extraction. Similarly, in 1950 one country (the USA) supplied more than half of the annual oil production, as in 2004 the leader Saudi Arabia supplied only $12.7 \%$ of the total world production. Saudi Arabia extracted nearly 500 million tons of oil in 2004; only Russia was able to get anywhere near that figure with some 456 million tons. The biggest oil producers include all countries with a production of over 100 million tons a year. The group of the biggest producers consists of four countries of the Near and Middle East (Saudi Arabia, Iran, the United Arab Emirates, and Kuwait), four American countries (USA, Mexico, Venezuela, and Canada); Europe is represented by Norway and the United Kingdom and Nigeria is the only representative of Africa. The Top 13 group is made complete by Russia and China.

Table 1

Oil Extraction in 2004

\begin{tabular}{|l|c|c|}
\hline Producer & Million tons & Share in world extraction (\%) \\
\hline Saudi Arabia & 492 & 12.7 \\
\hline Russia & 456 & 11.7 \\
\hline USA & 337 & 8.7 \\
\hline Iran & 203 & 5.2 \\
\hline Mexico & 192 & 4.9 \\
\hline China & 174 & 4.5 \\
\hline Venezuela & 153 & 3.9 \\
\hline Norway & 151 & 3.9 \\
\hline Canada & 146 & 3.8 \\
\hline Nigeria & 129 & 3.3 \\
\hline Others & 1455 & 37.4 \\
\hline World & $\mathbf{3 8 8 8}$ & $\mathbf{1 0 0 . 0}$ \\
\hline
\end{tabular}

Source: Key World Energy Statistics 2005. Cited work, p. 11, adapted by the author.

Oil processing plays a significant role in the location of oil industry. Crude oil is consumed minimally and the majority of the total production is processed in refineries. The processing refineries are located mainly outside the places of extraction and the decisive part of the refinery capacity is concentrated in the developed industrial countries (some $70 \%$ of the total capacity). The major processing regions around the world include: the Atlantic coast (Rotterdam, Antwerp, Hamburg, Le Havre), Marseille 
and Southern Italy in Europe; the region of New York and Mexican Gulf(New Orleans) in the USA; Tokyo Gulf in Japan; the Volga Basin in Russia; and the coast of the Persian Gulf. Approximately $57 \%$ of the total volume of processed oil belongs to the OECD countries. Compared to the 1970 s its share fell by $10 \%$. A similar drop was recorded in Latin America, whose current share is $6.3 \%$ compared to $9 \%$ in 1973 . On the contrary, the share in oil processing has increased in the developing countries of Africa and Asia (China not included). Whereas China processed 1.5\% of the total processed oil in 1973, it was already $6.5 \%$ in 2003 . $^{1}$

The territorial structure of oil refineries is influenced by two reversed tendencies. The first type, which prevails, is a market localization of refineries outside the places of extraction in the regions of consumption of oil products. The second tendency, on the contrary, directs the setting up of the refineries in the areas of the oil extraction. This tendency is typical for developing countries with big oil resources but also for areas with a favourable exposition not far from the main seaways for oil transport. That is true for e.g. the islands of Aruba and Curacao in the Caribbean Sea, Freeport on the Bahamas and some other islands in the Lesser Antilles. Singapore and Aden (Yemen Arab Republic) have an extraordinary position from this point of viewA similar trend can also be observed in some of the Persian Gulf countries, India, Brazil, etc.

The territories of the three countries with the biggest refinery capacity - the USA, Russia (former Soviet Union) and China - hold nearly $40 \%$ of the world total refinery capacity. The USA is the leading country with $20 \%$ of the world total capacity; the former Soviet Union has at its disposal 10\%, and China, which has recently got ahead of Japan, uses $7 \%$ of the world refinery capacity. Further important processing countries are Japan, South Korea, Germany, Italy, Canada, France, and the United Kingdom.

\section{Table 2}

Dynamism in oil processing in the regions worldwide in 1973 and 2003 (\%)

\begin{tabular}{|l|c|c|c|c|}
\hline Region & $\mathbf{1 9 7 3}$ & Ranking & $\mathbf{2 0 0 3}$ & Ranking \\
\hline OECD & 66.6 & 1st & 57.3 & 1st $\leftrightarrow$ \\
\hline former Soviet Union & 12.4 & 2nd & 7.3 & 4th $\downarrow$ \\
\hline Latin America & 9.0 & 3rd & 6.3 & 6th $\downarrow$ \\
\hline Middle East & 4.0 & 4th & 8.8 & 3rd $\uparrow$ \\
\hline Asia (China excl.) & 3.3 & 5th & 9.7 & 2nd $\uparrow$ \\
\hline China & 1.5 & 6th & 6.5 & 5th $\uparrow$ \\
\hline Europe (OECD excl.) & 1.5 & 7th & 0.8 & 8th $\downarrow$ \\
\hline Africa & 1.7 & 8th & 3.6 & 7th $\uparrow$ \\
\hline
\end{tabular}

Source: Key World Energy Statistics 2005. Cited work, p. 22, adapted by the author.

Oil is a significant commodity in foreign trade. A typical feature is the constantly growing traded volume of this raw material. More than half of the extracted volume is

$1 \quad$ Key World Energy Statistics 2005, citied work, page 22. 
exported annually. In 2004 it was $51.7 \%$ (over 2,000 million tons) of the total oil production. For the sake of comparison, it was 49.7\% (1,631 million tons) in 1995 while it was only $33 \%$ of the global production (254 million tons) in 1955. Asia is the main exporting region with a nearly 50\% share in the world exports (in the 1950s Asia supplied only $30 \%$ of the world exports). Saudi Arabia is the biggest exporter of oil today, covering $16.5 \%$ of the world exports. Russia is the second biggest oil exporter with $11 \%$ of the world exports; Norway has the third place with $6.7 \%{ }^{2}$. The USA is the biggest importer, to which more than a quarter of oil traded on international markets is headed. Other most significant importers are countries that do not dispose with notable reserves of oil, such as Japan, South Korea, Germany, and Italy.

\section{Table 3}

The biggest oil exporters and importers in 2004

\begin{tabular}{|l|r|r|l|r|r|}
\hline Exporter & Mt & \% & Importer & Mt & $\%$ \\
\hline Saudi Arabia & 333 & 16.5 & USA & 545 & 25.8 \\
\hline Russia & 228 & 11.3 & Japan & 209 & 9.9 \\
\hline Norway & 135 & 6.7 & South Korea & 108 & 5.1 \\
\hline Iran & 116 & 5.8 & Germany & 106 & 5.0 \\
\hline Nigeria & 112 & 5.6 & Italy & 92 & 4.3 \\
\hline Mexico & 105 & 5.2 & China & 91 & 4.3 \\
\hline Venezuela & 90 & 4.5 & India & 90 & 4.3 \\
\hline UAE & 88 & 4.4 & France & 85 & 4.0 \\
\hline Canada & 83 & 4.1 & Spain & 58 & 2.7 \\
\hline United Kingdom & 75 & 3.7 & The Netherlands & 57 & 2.7 \\
\hline Others & 648 & 32.2 & Others & 674 & 31.9 \\
\hline World & $\mathbf{2 0 1 3}$ & $\mathbf{1 0 0 . 0}$ & World & $\mathbf{2 1 1 5}$ & $\mathbf{1 0 0 . 0}$ \\
\hline
\end{tabular}

Source: Key World Energy Statistics 2005. Cited work, p. 11, adapted by the author.

\section{Localization changes in the gas industry}

The worldwide production of natural gas is steadily and significantly going up. In 2004, a total volume of 2,794 billion cubic meters of natural gas was extracted. The evidence for the increasing production is a comparison between the individual periods of the 20th century and the year 2004: e.g. in 1950 only 7\% was extracted, it was $37 \%$ in 1970, and even in 1990 it was only $73 \%$ of the current annual extraction.

2 Key World Energy Statistics 2005, citied work, page 11. 


\section{Figure 2}

Dynamism in the natural gas extraction in 1950-2004 (billion $\mathbf{m}^{3}$ )

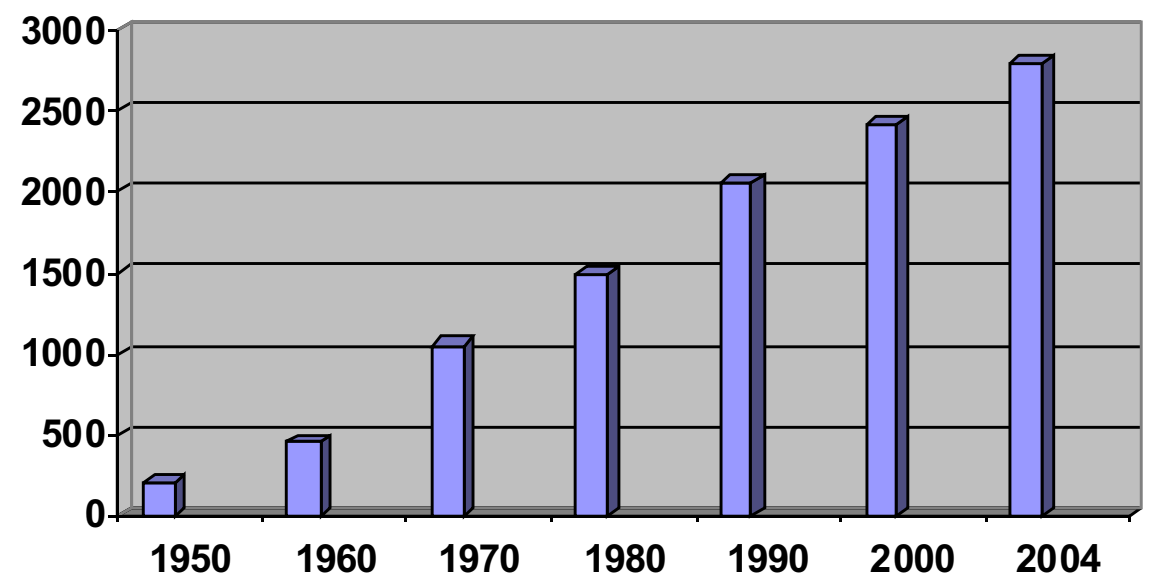

Source: Adapted by the author from: Rodionova, I. A, Gunakova, T. M.: Ekonomičeskaja geografija. Cited work, p. 128; Key World Energy Statistics 2005. Cited work, p. 12.

The territorial structure of both the extraction and consumption of natural gas is characterised by a significant concentration, which is substantially higher compared to oil. At present we can speak about a dominant position of two regions in natural gas production: North America and Eastern Europe, including Russia - they extract two thirds of the total volume of natural gas extracted. However, the territorial structure of gas extraction saw significant changes in the second half of the 20th century. The dominant position of North America was gradually weakening from the 1950s by the development of the extraction in Western and predominantly in Eastern Europe. In 1950 North America exploited over $90 \%$ of the total world production of natural gas; Western and Eastern Europe combined, some 6\%. In 1990, Eastern Europe became the region with the biggest extraction and the extraction also significantly grew in Western Europe and Asia. After the disintegration of the Soviet Union and the related decrease in its gas production, North America - the USA in particular - became the world leading gas producer. At the same time, new extracting countries appeared on the map of natural gas extraction such as Turkmenistan, Uzbekistan, and Azerbaijan.

The concentration of gas extraction is clearly visible in the evaluation of the individual states. The two leading countries - Russia and the USA - provide over $40 \%$ of the current production, and with Canada on the third place but with a significant lag behind the first two, they make up one half of the production. Russia was the biggest producer in 2004 with a $22 \%$ share in the total production. Further important producers of natural gas in Europe include the UK, the Netherlands and Norway; in Asia namely Iran, Indonesia and Saudi Arabia. Algeria is the biggest African producer of natural gas. The ten leading countries extract $70 \%$ of the total world production of 
natural gas. The position of other countries is also interesting as their combined share is constantly increasing; their production has doubled since 1990. These countries include Uzbekistan, Malaysia, Turkmenistan, the United Arab Emirates, etc.

\section{Table 4}

Extraction of natural gas in 1990 and 2004

\begin{tabular}{|c|c|c|c|c|c|}
\hline \multirow[t]{2}{*}{ Country } & \multicolumn{2}{|c|}{1990} & \multirow[t]{2}{*}{ Country } & \multicolumn{2}{|c|}{2004} \\
\hline & billion $\mathrm{m}^{3}$ & $\%$ & & billion $\mathrm{m}^{3}$ & $\%$ \\
\hline Soviet Union & 759 & 36.8 & Russia & 620 & 22.2 \\
\hline USA & 512 & 24.9 & USA & 532 & 19.0 \\
\hline Canada & 111 & 5.4 & Canada & 183 & 6.5 \\
\hline The Netherlands & 76 & 3.7 & United Kingdom & 101 & 3.6 \\
\hline United Kingdom & 46 & 2.2 & Algeria & 88 & 3.2 \\
\hline Algeria & 40 & 1.9 & The Netherlands & 86 & 3.1 \\
\hline Indonesia & 30 & 1.5 & Norway & 82 & 2.9 \\
\hline Saudi Arabia & 30 & 1.5 & Iran & 81 & 2.9 \\
\hline Norway & 28 & 1.4 & Indonesia & 79 & 2.8 \\
\hline Romania & 27 & 1.3 & Saudi Arabia & 64 & 2.3 \\
\hline TOP 10 & 1659 & 80.5 & TOP 10 & 1918 & 68.5 \\
\hline Others & 401 & 19.5 & Others & 877 & 31.5 \\
\hline World & 2060 & 100.0 & World & 2795 & 100.0 \\
\hline
\end{tabular}

Source: Alisov, N. V.,Chorev, B. S.: Ekonomičeskaja u socialnaja geografija mira, Moscow : Gardariki, 2003, p. 496; Key World Energy Statistics 2005. Cited work, p. 13, adapted by the author.

Just as the extraction of natural gas is concentrated, also the location of probably recoverable reserves ${ }^{3}$ in the world is characterised by being concentrated into two main regions (the probably recoverable reserves in 2003 were 172,700 billion $\mathrm{m} 3$ ). The biggest reserves are in the countries of the Near and Middle East, representing 41\% of the world reserves. The countries with the biggest reserves include Iran, Qatar, the United Arab Emirates and Saudi Arabia. Russia is the second most significant area together with the former Soviet Union countries with a 32\% share. Africa and the Pacific region have roughly the same share in the total reserves: some $14.5 \%$ each. North and Latin Americas are sub- stantially weaker regions (some 4\% each) and only $3.3 \%$ belongs to Western Europe. Russia has the best prospects among the world superpowers with one quarter of the world reserves. It is a very significant fact that the prospective deposits of natural gas are located in seas and oceans, namely in the Arctic Ocean, which is a decisive factor in the case of Russia. The reserves of gas in the developed industrial countries represent less than $10 \%{ }^{4}$

3 Reserves recoverable when using the current technological and technical means.

4 www.onlinegb.ruhrgas.de/down/Magazin/Magazin.pdf 
The world trade in natural gas is growing hand in hand with the extraction, and in the year 2004 it achieved nearly 800 billion m3. Although a relatively small quantity of the annual extraction is subject to foreign trade, this share is slowly growing as well $-28 \%$ of the world extraction was traded in 2004 . The crucial part of the trade is made up by the supplies within the individual regions. The regions with the prevailing intra-regional exports are predominantly Eastern Europe and North America, which provide $80 \%$ of the supplies of natural gas. A significantly lower volume accounts for the interregional trade. The most significant flows go from Eastern to Western Europe and from Africa to Western Europe. One quarter of the exports of natural gas is currently made up of liquefied natural gas the supplies of which are the specialization of namely South-East Asia (Indonesia, Malaysia, and Brunei); Australia and the USA export this predominantly to Japan, South Korea, and Taiwan. A smaller quantity of liquefied natural gas heads from Africa (Algeria) and the Near East for Western Europe. Russia is the biggest exporter of natural gas with a $25 \%$ share in the total exports. Three quarters of Russian exports head for the European territory (including Turkey) and one quarter goes to the states of the former Soviet Union. Russia exports nearly $40 \%$ of its domestic production and covers $19 \%$ of the imports of Western Europe, $58 \%$ of Central Europe and $45 \%$ of the Balkan states. The Russian gas represents $39 \%$ of the imports of Germany, $26 \%$ of Italian imports, and $68 \%$ of the imports of the Czech Republic. Countries totally dependent on Russian supplies include Finland, Albania, Macedonia and the Baltic States of Estonia, Lithuania and Latvia. ${ }^{5}$

\section{Table 5}

The biggest exporters and importers of natural gas in 2004

\begin{tabular}{|l|c|c|l|c|c|}
\hline Exporter & billion $\mathbf{~ m}^{3}$ & $\%$ & Importer & billion $\mathbf{~}^{3}$ & $\%$ \\
\hline Russia & 194.8 & 24.6 & USA & 120.6 & 15.2 \\
\hline Canada & 103.1 & 13.1 & Germany & 90.1 & 11.3 \\
\hline Norway & 75.9 & 9.6 & Japan & 81.2 & 10.2 \\
\hline Algeria & 64.5 & 8.2 & Italy & 67.9 & 8.5 \\
\hline The Netherlands & 53.6 & 6.8 & Ukraine & 54.4 & 6.8 \\
\hline Turkmenistan & 44.1 & 5.6 & France & 44.0 & 5.5 \\
\hline Indonesia & 38.6 & 4.9 & South Korea & 29.0 & 3.7 \\
\hline Malaysia & 25.5 & 3.2 & Spain & 26.9 & 3.4 \\
\hline Qatar & 24.4 & 3.1 & Turkey & 21.7 & 2.7 \\
\hline USA & 24.2 & 3.1 & Belarus & 19.6 & 2.5 \\
\hline Others & 139.5 & 17.7 & Others & 238.9 & 30.1 \\
\hline World & 788.2 & 100.0 & World & 794.4 & 100.0 \\
\hline
\end{tabular}

Source: Key World Energy Statistics 2005. Cited work, p. 13, adapted by the author.

5 Natural Gas Information 2005. OECD, Part II, tab. 3, 14. 


\section{Localization changes in coal industry}

At present the extraction of coal enjoys a stable trend while the proportion between the black coal and the brown coal maintains, despite a certain drop in the extraction of brown coal, the ratio of approximately 5:1 in favour of black coal.4,629 million tons of black coal were extracted worldwide in $2004 .^{6}$ The dominant position of the two leading regions - Asia and North America - shows the imbalance in the allocation of the world extraction. Asia and North America represent $45 \%$ and nearly $30 \%$ of the world production of black coal, respectively. ${ }^{7}$ The shares of other regions make up less than $10 \%$. Only Russia and the territory of the former Soviet Union approach this frontier.

\section{Figure 3}

Dynamism in black coal extraction in 1950 - 2004 (million tons)

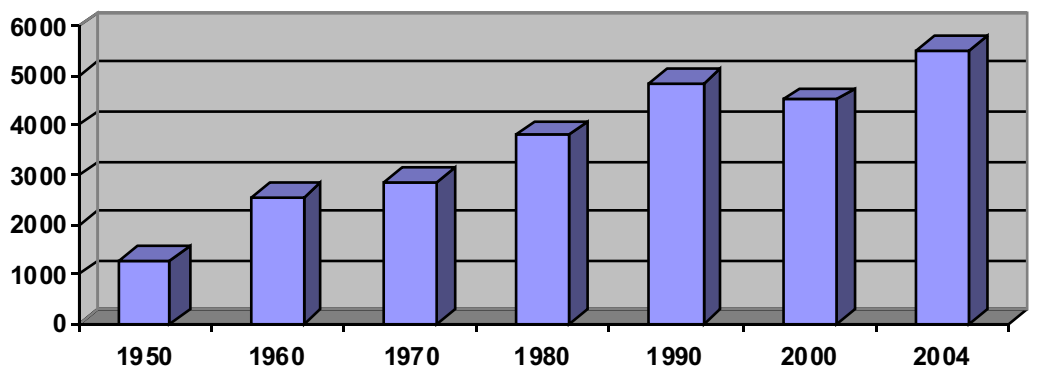

Source: Adapted by the author, based on: Rodionova, I. A, Gunakova, T. M.: Ekonomičeskaja geografija. Cited work, p. 131; Key World Energy Statistics 2005. Cited work, p. 15.

The coal industry has achieved significant changes in the territorial deployment of the black coal extraction over the last decades. The localization of the extraction was influenced by a number of factors such as: oil crisis, ineffective extraction in some traditional regions of developed countries, growing demand for coal in developing regions, and also the transition to a market economy in the case of the Central and Eastern European countries. The crisis of the coal industry in Western Europe and Japan, ineffective underground extraction and exploitation significantly changed the geography of the extraction. Developed countries saw the prevalent tendency towards rationalization of the economy with smaller utilization of ineffective coal burning. The constraining factors were the constantly greater negative environmental impacts. The production of coal dropped in some traditional extraction areas of Western European countries such as in northern France, the coal extraction even ended in Belgium and the Netherlands. Even the United Kingdom became a net importer of coal. Despite this, the coal extraction achieved a growth in the 1980s. Similar tendencies led to growth of the extraction in other countries (Canada, Latin America, Indonesia, Columbia, and Venezuela). The internal demand stimulated the growth of extraction namely in China and India. The opening and exploitation of open-cast

6 Key World Energy Statistics 2005, s. 32.

7 Rodionova, I. A, Gunakova, T. M.: Ekonomičeskaja geografija, p. 132. 
coal fields was a key moment in the change of the localization of extraction. The exposition of fields within good accessibility in littoral zones increased the efficiency even further. The open-cast method of extraction allows $4 / 5$ of the fields in Canada and 1/3 of the fields in Australia to be exploited. The drop in black coal extraction in Eastern Europe was influenced namely by the transition of the region to a market economy system with related economic structural changes. The biggest declines in the extraction were seen in Russia and Poland. Despite the fact that by the 1990s there were significant changes in the territorial structure of coal extraction (namely black coal), the geography of the consumption did not show such significant changes. A typical feature of the territorial structure of the localization of coal industry worldwide is more than $80 \%$ share of three regions - Asia, North America and Eastern Europe - in both the world extraction and consumption of black coal.

\section{Table 6}

World extraction of black and brown coal 2004

\begin{tabular}{|l|c|c|c|c|}
\hline Country & Black coal (Mt) & $\begin{array}{c}\text { Black coal } \\
\text { (\%) }\end{array}$ & $\begin{array}{c}\text { Brown coal } \\
\text { (Mt) }\end{array}$ & $\begin{array}{c}\text { Brown coal } \\
\text { (\%) }\end{array}$ \\
\hline China & $1956^{\star}$ & $42.3^{*}$ & - & -6 \\
\hline USA & 933 & 20.2 & 29 & 3.3 \\
\hline India & 373 & 8.1 & 69 & 7.8 \\
\hline Australia & 285 & 6.2 & 0 & 0.0 \\
\hline Latin America & 238 & 5.1 & 70 & 8.0 \\
\hline Russia & 210 & 4.5 & 0 & 0.0 \\
\hline Indonesia & 129 & 2.8 & 61 & 6.9 \\
\hline Poland & 100 & 2.2 & 4 & 0.5 \\
\hline Kazakhstan & 83 & 1.8 & 0 & 0.0 \\
\hline Ukraine & 62 & 1.3 & 570 & 64.8 \\
\hline Others & 260 & 5.6 & $\mathbf{8 7 9}$ & 100.0 \\
\hline World & 4629 & 100.0 & & 0.0 \\
\hline
\end{tabular}

* Including brown coal extraction (the share of brown coal extraction in total extraction in China is approx. $4 \%$ ).

Source: Key World Energy Statistics 2005. Cited work, p. 15, adapted by the author.

The first place in the production of black coal in the 1990s belonged to China, which overtook the so-far leading America and achieved a production of over one billion tons a year. Thus at present China extracts more than $40 \%$ of the world production of black coal. The USA, ranking second, have a roughly $20 \%$ share in the world production. This means a dominant position of only two countries. India, ranking third, extracts only $8 \%$, and the other most important producers - Australia, Latin America, Russia, Indonesia, Poland, Kazakhstan and the Ukraine - combined make up only a quarter share in the world extraction. 
Brown coal extraction represented 879 million tons in 2004 and did not by far reach the maximum of 1989 (1.5 billion tons). Brown coal is used mainly as energy feedstock of largely local significance. It has the greatest economic importance in countries with a lack of other sources of energy (e.g., Greece, Hungary, and Bulgaria). Europe has traditionally been the main region of brown coal extraction, representing two thirds of the world extraction. Germany is the biggest producer with a $20 \%$ share in the world production, followed by Russia (8\%), the USA, Australia, Poland, the Czech Republic, and Turkey.

World exports of coal in 2004 reached 774 million tons in total, which was 530\% of the exports in 1955. Over the whole 20th century, the development of the foreign trade in coal was influenced by the changing position of oil in the world economy. In the 1950 s and 1960s there was a significant drop in world exports due to a rapid take-off of oil as a source of energy. After the oil crisis the position of coal on the world markets consolidated and nowadays some $16 \%$ of the total coal extraction is exported. The changes in the deployment of coal extraction reflected also in the territorial structure of coal exports, the distinctive feature of which is its concentration in three regions: Australia, North America and Eastern Europe. While the trio of the main regions cover $70 \%$ of the coal exports, compared to the year 1950 the mentioned concentration made up almost $100 \%$ except that Europe held the position of Australia. With respect to the development of the extraction in remote destinations and their export determination, there has been a considerable development in the transport of coal by sea. Its total share in the total transport of coal makes up more than $60 \%$ at present.

\section{Table 7}

Coal exports and imports 2004

\begin{tabular}{|l|c|c|l|c|c|}
\hline Country & $\begin{array}{c}\text { Exports } \\
(\mathbf{M t})\end{array}$ & $\begin{array}{c}\text { Exports } \\
(\mathbf{\%})\end{array}$ & Country & $\begin{array}{c}\text { Imports } \\
(\mathbf{M t})\end{array}$ & $\begin{array}{c}\text { Imports } \\
\text { (\%) }\end{array}$ \\
\hline Australia & 218 & 28.9 & Japan & 183 & 24.30 \\
\hline Indonesia & 107 & 14.2 & South Korea & 79 & 10.50 \\
\hline China & 87 & 11.5 & Taiwan & 60 & 7.95 \\
\hline South Africa & 66 & 8.7 & Germany & 39 & 5.20 \\
\hline Russia & 65 & 8.6 & UK & 36 & 4.80 \\
\hline Columbia & 52 & 6.9 & India & 31 & 4.10 \\
\hline USA & 43 & 5.7 & Italy & 25 & 3.30 \\
\hline Canada & 27 & 3.6 & USA & 25 & 3.30 \\
\hline Kazakhstan & 22 & 2.9 & Spain & 24 & 3.20 \\
\hline Poland & 20 & 2.6 & The Netherlands & 23 & 3.10 \\
\hline Others & 48 & 6.3 & Others & 229 & 30.40 \\
\hline World & 755 & 100.0 & World & 754 & 100.00 \\
\hline
\end{tabular}

Source: Key World Energy Statistics 2005. Cited work, p. 15, adapted by the author.

Australia is currently the biggest coal exporter, which has strengthened its position after the year 2000. In 2004 it covered almost 30\% of the world exports of coal. Indonesia occupied the second place (with $14.2 \%$ of exports) which some 10 years before did not export virtually any coal and its total production was minimal. China is 
the third biggest exporter ( $11.5 \%$ of exports). The first ten biggest exporters supply the world markets with more than $90 \%$ of coal. The three biggest importers worldwide are the countries of South East Asia: Japan, South Korea and Taiwan. Their total share in the world imports makes up over $40 \%$. Japan is the biggest importer with a $24 \%$ share in the world imports. In the last decade, the biggest changes in the territorial structure of the foreign trade in coal included a transformation of some exporting countries to importing ones (e.g. UK, Germany, the Netherlands) as well as a rapid increase in exports in some developing countries together with a process of strengthening their position among the world exporters (e.g., Indonesia, Columbia, Venezuela).

The main transport streams go from Australia to Japan and South Korea, from Australia and Africa (South Africa) to Western Europe, and from the USA to Western Europe. At present, fuel coal and cokable coal make up roughly the same shares in the world exports. The Asia-Pacific region is the biggest consumer of coal with a $60 \%$ share in the total consumption. In the last ten years, its share has grown considerably, namely due to the growing demand in China and India. North America with a 21\% share in the consumption takes the second place, followed by Eastern Europe. ${ }^{8}$

\section{Conclusions - prospects for the development}

The changes in the deployment of the present-day energy industry are influenced by the following factors: growing volume of the world economy and related growth in consumption; population pressure on the world and the disability of developing countries to achieve lower energy intensity due to the lack of advanced technologies as well as the unambiguous dependence on the growth in primary energy in these countries (namely in China and India); another factor is the different structures of energy sources in the individual regions and countries with tendencies to permanent changes; and more and more important is the ecological factor, predominantly in developed industrial countries. ${ }^{9}$

In addition to the unambiguously richest regions of the Near and Middle East, Promising regions with great reserves of oil which are likely to form the territorial structure of extraction in the future include Alaska with untouched reserves located within a protected Arctic range. Very promising is also the Canadian province of Alberta, which is rich in oil sands the extraction of which could increase Canadian oil production by $40 \%$ by the year 2015 . The Mexican Gulf, exploited by the USA and Mexico, should remain an important area as well. West Africa is a relatively new oil region where great exploration is ongoing in great depths of the Gulf of Guinea; in view of its reserves experts compare it to the North Sea. The East African coast of the Indian ocean is in a similar situation. The richest reserves of oil near the European market can be found in Libya. It is clear that a gradual exploitation of the oil and natural gas reserves in the North Sea raises the dependence of Europe on Russia even further, where very promising oilfields can be found in North Siberia and the Sakhalin Island.

8 Coal Facts 2005 Edition. World Coal Institute, october 2005; www.worldcoal.org.

9 Kopačka, L.: Ropa a plyn v dnešním světě. Geografické rozhledy. Praha : Kartografie, 2005-2006, no. 1, pp. 2 and 3. 
The main trend in the changing territorial structure of oil and natural gas extraction in the upcoming years is going to be the growing extraction from the sea shelf. At present more than a third of the world oil production is exploited from the sea. In compliance with the growing oil price a number of countries focus on more and more remote offshore areas. Extraction takes place in depths reaching 800 metres in the distance of 200-500 kilometres from the coast. The best-known oilfields can be found in the Persian Gulf near the south-east coast of the Arabian Peninsula, in the Mexican Gulf, in the North Sea, off the coast of Alaska, in California, off the West African coast, and within the territory of the South East Asian islands. The orientation towards extraction in individual countries is also influenced by the very localization of reserves. E.g. in Norway and the UK, $100 \%$ of the oilfields is in the sea; in the case of the USA it is more than one half; two thirds in Brunei and Qatar; over $90 \%$ in Australia, and so on. According to the latest estimations, $40 \%$ of the reserves in South East Asia are found deep in the sea. About 50 billion barrels of oil ${ }^{10}$ lying in the seas of the Asia-Pacific region make up only $11 \%$ of sea oil reserves worldwide.

Localization changes in the deployment of the oil industry in future can also be expected in the proliferation of unconventional extraction, namely by using bituminous sedimentary (oil sands). New extraction capacities are localized in the areas of North Canada. The most significant reserves can be found in Alberta province (Athabasca, Peace River, Cold Lake), where according to the estimation as much oil in oil sands is hidden as in Saudi Arabia.

The deployment of refineries in the following years will be dependent on economic and economic-geographical peculiarities as well as on the specific needs of individual countries or regions. The localization of processing plants in developing countries is stimulated by strict environmental standards in developed countries and we can speak about a shift of environmentally bad productions to developing countries. The mentioned tendency towards oil processing in developing countries is enhanced by the effort of these countries to develop their own refinery sector namely in order to export oil derivatives. Imports of semi-finished products from the Persian Gulf have a very significant effect on reducing refinery capacities in Western Europe; thanks to the cheaper production the Persian Gulf stands comparison to refineries in Japan and North America.

Probably even more dynamic changes can be expected in the localization of natural gas extraction, which is considered a promising fuel in the upcoming years. Vast world reserves enable the growth in consumption and thus in the production. The growing potential is determined by a developed transport infrastructure and also by the positive characteristics of this resource. By 2030 the world consumption of natural gas is estimated to increase by $70-130 \%$ with respect to the development of the world economy and the price development of this resource. Namely, more massive future utilization of natural gas is expected in electricity production and in transport. With growing consumption of gas we can speak about a modernization of gas infrastructures and the localization of new transport routes - gas pipelines and gas storage tanks. A main change in the localization of natural gas transport at the beginning on new 
millennium will be the construction of arterial pipelines - namely the Trans-Asian system which interconnects Europe, Asia and the Pacific and becomes the most important system of gas pipelines in the world. The main objective is to link Central Asia and Siberia with China, South Asia and the Middle East. Liquefied gas continues to increase its share in natural gas transportation. The construction of facilities for gas liquefaction is expected to a large degree in the Persian Gulf countries.

In the near future the dependence of developed regions on natural gas imports will grow and on the other hand, a certain stagnation of domestic production can be expected in connection with the reserves in individual countries. Gas exports from Russia, Africa and Asia will be even more important. Besides traditional exporting countries (Russia, Canada, Algeria, and Norway), exports from the Persian Gulf countries (Iran, Qatar, Oman, and UAE) and the Caspian region (Turkmenistan, Kazakhstan) also take place. Moreover, natural gas exports from the countries of South East Asia (Indonesia, Malaysia), Australia and new suppliers in Africa (Nigeria, Libya) will significantly increase. The changes in the geography of exports as well as the utilization of transport routes will be influenced namely by a growing demand for natural gas in the traditional centres - the EU, the USA and Japan - but also in the fast growing consumption markets of China, India, South Korea, and Turkey.

The biggest changes in the deployment of natural gas extraction are expected in the shelf areas of the seas and oceans. At present, approximately one third of the world production of natural gas is exploited from the sea and the biggest share belongs to the Mexican Gulf, the Caribbean Sea and the North Sea. In future, the development of extraction is expected namely in the eastern part of the Indian Ocean and in the Persian Gulf, as well as in the Atlantic off the coast of Canada, Brazil and Nigeria, and in the Arctic Ocean off the coast of Russia (Barents Sea) and the USA. Extraction centres localized in the Sea of Okhotsk and in the area of Sakhalin will serve supplies to East Asia.

\section{References}

ALISOV, N. V.; CHOREV, B. S. 2003. Ekonomičeskaja i socijalnaja geografija mira. Moscow : Gardariki, 2003. ISBN 5-8297-0029-8.

BULATOV, A. S. (ed.). 2003. Mirovaja ekonomika. Moscow : Ekonomist, 2003. ISBN 5-98118-049-8.

Coal Facts 2005 Edition. World Coal Institute, October 2005. www.worldcoal.org.

DICKEn, P. 2003. Global Shift. New York : Guilford, 2003. ISBN 1572308990.

Der Fischer Weltalmanach 2006. Frankfurt am Main : Fischer Verlag, 2006. ISBN 3-596-729068.

Energy \& Transport in Figures 2005. Brussel : Office for Official Publications of the European Communities, 2006. www.europa.eu.int/comm/dgs/energy/_transport/figures/posketbook/2005_e.htm.

Key World Energy Statistics 2005. Paris : International Energy Agency, 2005, s. 27. www.iea.org.

KNOX, P.; AGNEW, J.; McCARTHY, L. 2003. The Geography of the World Economy. London : Hodder Arnold, 2003. ISBN 0-340-80712-I.

KOPAČKA, L. 2005. Ropa a plyn v dnešním světě. Geografické rozhledy. 2005, roč. 15, č.1. 
Natural Gas Information 2005. OECD, Part II, tab. 3, 14. ISBN 9264108998.

Oil \& Gas Journal. 2004, vol. 102, no. 47, December 20.

PECK, J.; WAI-CHUNG, Y. (eds.). 2003. Remaking the Global Economy. London : SAGE Publications. ISBN 0-7619-4897-X.

Renewables in Global Energy Supply. Paris : IEA, November 2005. www.iea.org.

Renewables for Power Generation, Status and Prospects. Paris : OECD/IEA, 2003. www.iea.org. Renewable Energy policy in IEA Countries, Paris : OECD/IEA, 1997. www.iea.org.

Review of Maritime Transport 2005. Geneva : UNCTAD, 2005. www.unctad.org/en/docs/rmt2005_en.pdf.

Rodionova, I. A.; Bunakova, T. M. 2004. Ekonomičeskaja geografija. Moscow : Moskovskij licej, 2004. ISBN 5-7611-0366-4.

VOŠTA, M. 2006. Změny v rozmístění světového hospodářství. Praha : VŠE, Nakladatelství Oeconomica, 2006. ISBN 80-245-1105-3.

www.onlinegb.ruhrgas.de/down/Magazin/Magazin.pdf.

\title{
GLOBAL CHANGES AND NEW TRENDS WITHIN THE TERRITORIAL STRUCTURE OF THE OIL, GAS AND COAL INDUSTRIES
}

\begin{abstract}
The development of power engineering in the last decades has corresponded to the rapidly growing demand for primary energy in the world. The economic, political and environmental problems which arise in connection to the exploitation and processing of primary energy resources has taken on a global dimension. The increased use of oil and natural gas has had a very important multiplication effect on the world economy. It has caused changes in the structure as well as the location of the power industry and in other industries, namely chemical and transportation. The important moments of the last decade which have influenced the total consumption of primary energy were namely the increasing energy demand in Eastern Europe, South-East Asia, India, China, and Latin America. In the developing regions the important drivers of the demand have been the development of industrial production and continuing population pressure. In Eastern Europe it is necessary to stress the connection between increasing living standards and the development of small and medium enterprises. A very strong regional differentiation is characteristic for the entire power engineering sector . The deposits of energy resources, namely of oil and natural gas, their extraction, consumption and processing are characterized by significant territorial imbalances. For example, the OPEC countries are assumed to dispose of approximately $80 \%$ of the world reserves of oil and they have a $40 \%$ share in the total world production, but their own consumption is substantially lower. A similar imbalance also exists in the case of natural gas. The basic development tendency in the territorial structure of the extraction and consumption of both oil and natural gas will be a constantly deepening asymmetry between the extraction, processing and consumption.
\end{abstract}

Keywords: localization changes, oil, natural gas, coal, prospects, new trends

JEL Classification: Q3 